\title{
Mastoid cavity obliteration in open cavity type (MRM) with fibro fatty tissue and subcutaneous periosteal flaps study conducted at RIMS college Ongole ENT department 2015-2016.
}

\author{
Dr. K.Ravi, M.S. Associate Professor, \\ Dr. S.Kalyan Kumar, M.S., Assistant Professor, \\ Department of ENT, Rajiv Gandhi Institute of Medical Sciences, Ongole.
}

\begin{abstract}
A mastoid cavity resulting from a canal wall down can result in major morbidity for patients due to chronic otorhea and infection, difficulty with hearing aids and vertigo with temperature changes. Mastoid obliteration recreates the normal anatomy to certain extent avoid such morbidity. Few have the studied the quality of life benefited by this procedure. Open cavity mastiodectomy techniques applied for chronic suppurative otitis media with attico antral disease cause some cavity problems, these pts complaints of vertigo in cold weather and during swimming, other problems are difficulty in wearing hearing aids, frequent fungal infections and exuberant wax, and wide meatoplasty which is non aesthetic and these pts need lifelong otological care for debris that accumulates due to insufficient self cleaning mechanism of mastiodectomy cavities, various obliteration techniques have been recommended to eliminate open cavity problem.
\end{abstract}

\begin{abstract}
Aim \& objectives
To study surgical results of mastoid cavity obliteration, efficacy of different methods of mastoid obliteration cavity problems and need of cavity care.

Materials and methods

Retrospective study was carried out in a tertiary care center involving 100 pts from 2015 June - May 2016 having csom with attico antral type of disease who underwent MRM with the cavity obliterated with fibro fatty tissues, cartilage or periosteal flaps . The indication for MRM were patients with extensive cholesteatoma,with extra cranial complications, patients with poor compliance for follow up, patients presented with tubo tympanic type, of csom and those with sensorineural hearing loss and intracranial complications were excluded from the study.

A detailed history and through ENT examination was done in all patients. Microscopic examination of the affected ears was done to confirm the findings . The lateral oblique view of both mastoids were taken ,HRCT temporal bone was done in these cases where clinical diagnosis is not clear pure tone audiometry and tuning fork tests were done preoperatively and informed written consent was obtained .

Results and conclusion

In our study the minimum age of the pt was 10 years and maximum age was 55 yrs. Maximum no of pts i.e. $35 \%$ in the age group 11-20 yrs followed by 34\% in the age group of 21-30 yrs . out of 100 pts male 65 females 35 the male to female ratio $1.35 ; 1 \quad 65 \%$ of the patents belong to rural area $35 \%$ belongs to urban area. $100 \%$ patients presented with ear discharge ,94\% pts presented with hearig loss ,3\% of cases presented with facial palsy cholesteatoma was found in all 100 cases , postero superior perforations found in $70 \%$ in 30 ears while 20\% pts had attic perforation ,30 ears were found to have discharge at 3 months followup 18 ears became dry after medical treatment. At the end of 1 year, well healed cavity with intact graft was seen in 100 cases and 8 cases were advised revision surgery

Incidence of discharge, debris,giddiness pain ware reduced in oblitetarating cavities healing was better in obliterating cavity . cavity oblitearing with fibrofatty tissues and flap had better and early epithelisation as compared to cartilage .
\end{abstract}

Keywords

- Mastiodectomy

- Obliteration,

- Fibrofatty tissue

- Cartilage

- Cholisteatoma

- $\quad$ Periosteal flaps 


\section{Operative technique}

Most of the procedures done under local anaesthesia except in children and pts with anxiety. Preoperative cleaning of the ear canal was done to clear the debris and preop antibiotics were given for period of 5 days prior to surgery. Pts were kept in supine position with ring under the head and head is tilted to one side and $1 / 2 \mathrm{cc}$ pentazocine with $1 \mathrm{cc}$ phenergan iv given slowly $10 \mathrm{mts}$ prior the procedure for sedation. Thorough scrubbing done all around the ear, after proper draping infiltration given with $1 \%$ xylocaine mixed with adrenaline around the pinna to block various nerveres like Greater auricular, auriculo temporal,auricular branch of vagus,lesser occipital nerve, c2,c3, c4nerves. And a curved wildes inscion given few mm behind the retro auricular groove, and skin subcutaneous tissues incised and Temporalis facial graft adequeately harvested mastoid bone palpated with the help of coagulation diathermy $\mathrm{T}$ shaped inscion given over the mastoid periosteam and flaps are bulged with infilatration and stripped from the bone with periosteal elevatior mastoid bone exposed properly by postaural approach,trans flap elevated,posterior retraction attic defect ascertained. Mac evans Traingle defined and drilled the bone to reach the antrum and cavity is made and all the structures sinus plate, dural plate exposed cholesteatomatous sac identified and tracked all around and bridge, removed the facial ridge lowered buttresses were reduced Facial nerve area properly protected, ossciles exposed and sac is further dissected and removed completely in aditus attic area and hypotympanum and dissection continued to clear the disease in facial recess and sinus tympani, ossicles were reconstructed by doing ossiculoplasty, meatoplasty done and bits of fibrofatty tissue,bits of cartilage from the conchal cartilage harvested and preserved in saline bowl. posterior Periostel flap together with postauriclur muscle elvated and retracted and pinna retracted with mollison haestatic retractor, and temparalis facial graft kept below the elvated Tympano meatal flap and mastoid cavity filled with bits of fibrofatty tissue and cartilage and perisotel flap reposited in the cavity and temporalis facial graft adjusted and kept over these tissues . and middle ear stuffed with gelfoam and external ear packed with gelfoam and beatadine wick . and inscised wound is sutured with 1 with silk and mastoid dressing done . and pts were kept in postop wards high $3^{\text {rd }}$ generation cephalosporins , and amikacin , were given for a period of 7 days and analgesics were given to relieve the pain strict aspectic precautions were taken during the changing of the dressings and sutured were removed on the 9 th postop day and all the pts dischared and reviewed in the opd for a follow period of 6months the cavities are slowly epithelised and dried ,and meatoplasty is aesthetic and ear canal size is little bit wider quietly accepted by the pts and ears become dried with in a period of 3- 4 months and reviewd after 6 months and one year all the pts were satisfied, symptom free with dry, safety ears .

\section{Results}

This study was done between years June 2015 and May 2016 in more than 100 pts . all pts were followed upto one year External auditory canal were smooth and healthy. In all patients epithelisation was complete after the second month of the operation none had recurrent osteitis,cholesteatoma or granulation. None of the pts returned with vertigo induced by cold air or swimming, no aesthetic disapproval occurred. Introducing the hearing aid placement into the EAC was easy and almost natural. In some pts conchal peichondritis emerged and soon after the operation and was treated with high antibiotics and some of the noted with mild facial paresis which were later recovered.

\section{Discussion}

The present study was based on 100 pts who underwent modified radical mastiodectiomy with cavity obliteration with fibrofatty tissue and postauricular pedicle flap during a period of June 2015 to May 2016.

In our study the patients were between $11 \mathrm{yrs}$ to $55 \mathrm{yrs}$ of age, with mean age group of 30 years maximum no of pts i.e. 56 (35\%)in the age group 11-20years followed by 48 patients (34.3\%) in the age group of 21-30 years the overall sex distribution showed male preponderance. $60 \%$ were males with while females $40 \%$. The male to female ratio is $1.5 ; 1$ Majority of these pts belong to rural areas than urban areas.

The diagnosis of cholestatoma made by clinical examination with otoscopy. The cases in which diagnosis was not obivious, CT scan demonstrated soft tissue mass with charastreic ossicular discontinuity and bone erosion. Commonest complaint is otorrohea $(100 \%)$ and these cases presented with foul smelling ear discharge,,Blood stained discharge noted due to granulations and polypi, hearing loss presents in most of these cases otlagia presents in $10 \%$ of the cases Giddiness presents in 20 cases only $10 \%$ pts presents with tinnitus . None of these cases presented with intracranial complications.

Cholesteatoma was present in 100 cases (100\%), and attic perforation noted in 52 cases (33\%) 28 pts presented with aural polyps , granulation tissue presented with 34 patients (21\%)This was in Accordance with Proctor which suggested the association of granulation tissue in $93-95 \%$ of cases of cholesteatoma Retraction pockets were seen in few cases $10 \%$ ossicular defects were seen in all cases.

In our study over all success rate was 96 (100 ears) 4 cases were advised revision surgery due to recurrent /residual disease 


\section{References}

[1]. Black B Mastiodectomy elimination. Am J Otol19;551-557

[2]. Gorur K,Ozcanc Unal M, (2002) Causes of failure in open cavity mastiodectomy

[3]. Hoffmann DF,Fragan PA,Taylor B 1997 Reduction meatoplasty

[4]. JacksonCG,schall DG,Glasscock ME3rd ,Macias JD,widick MH, a surgical solution for the difficult chronic ear.Am J Otol 17;714 (pubMed)

[5]. Mosher HP (1911) A method of filling the excavated mastoid with a flap from the back of the auricle. Laryngoscope 21;11581163.

[6]. Ojala K, Sorri M , Sipilap,Palva A (1982) Late changes in ear canal volumes after mastoid obliteration . Arch otolaryngol 108;208-209 (PubMed)

[7]. Sade J,Weinberg J ,Berco E,Halvey A (1982) the marsupialized ( radical) Mastiod.J Laryngol Otlo96;869-875

\section{ATTIC PERORATION}
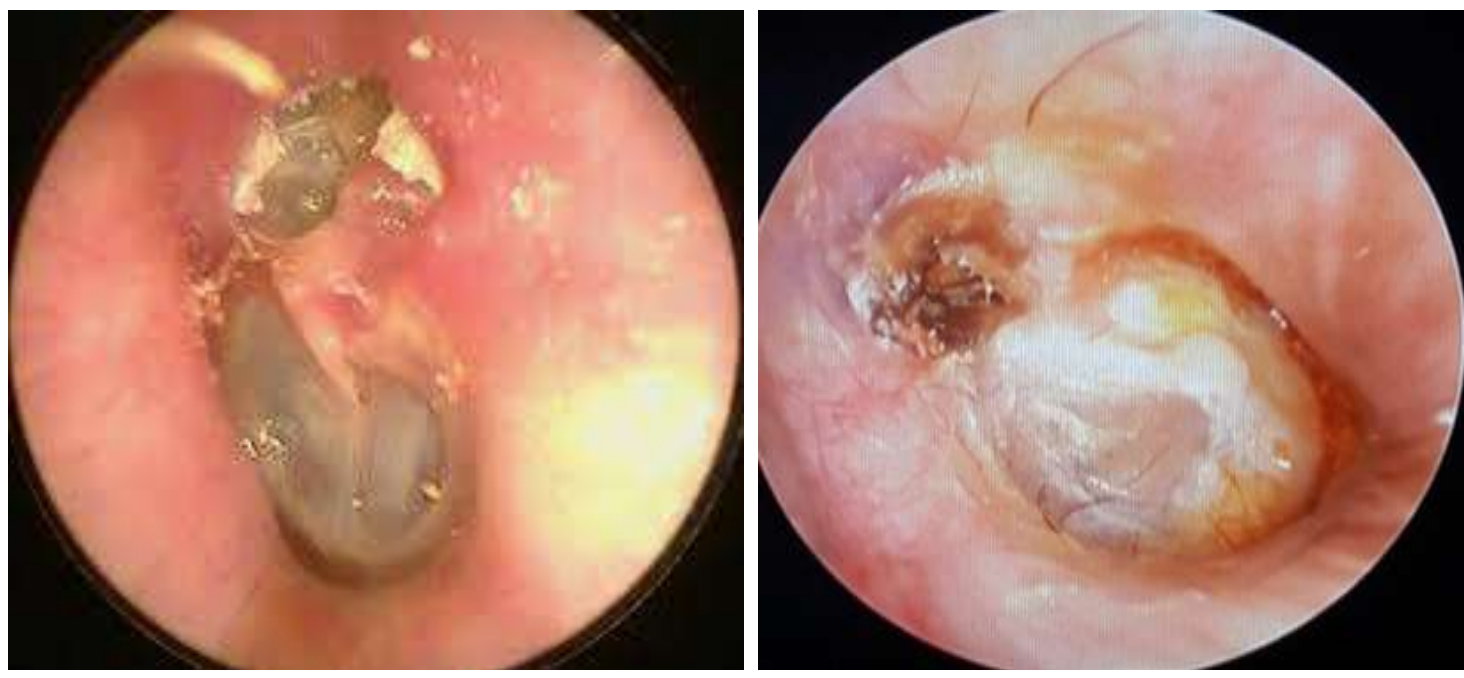

Removal of fibrofatty tissue and making of pedicleflap(postauricular)
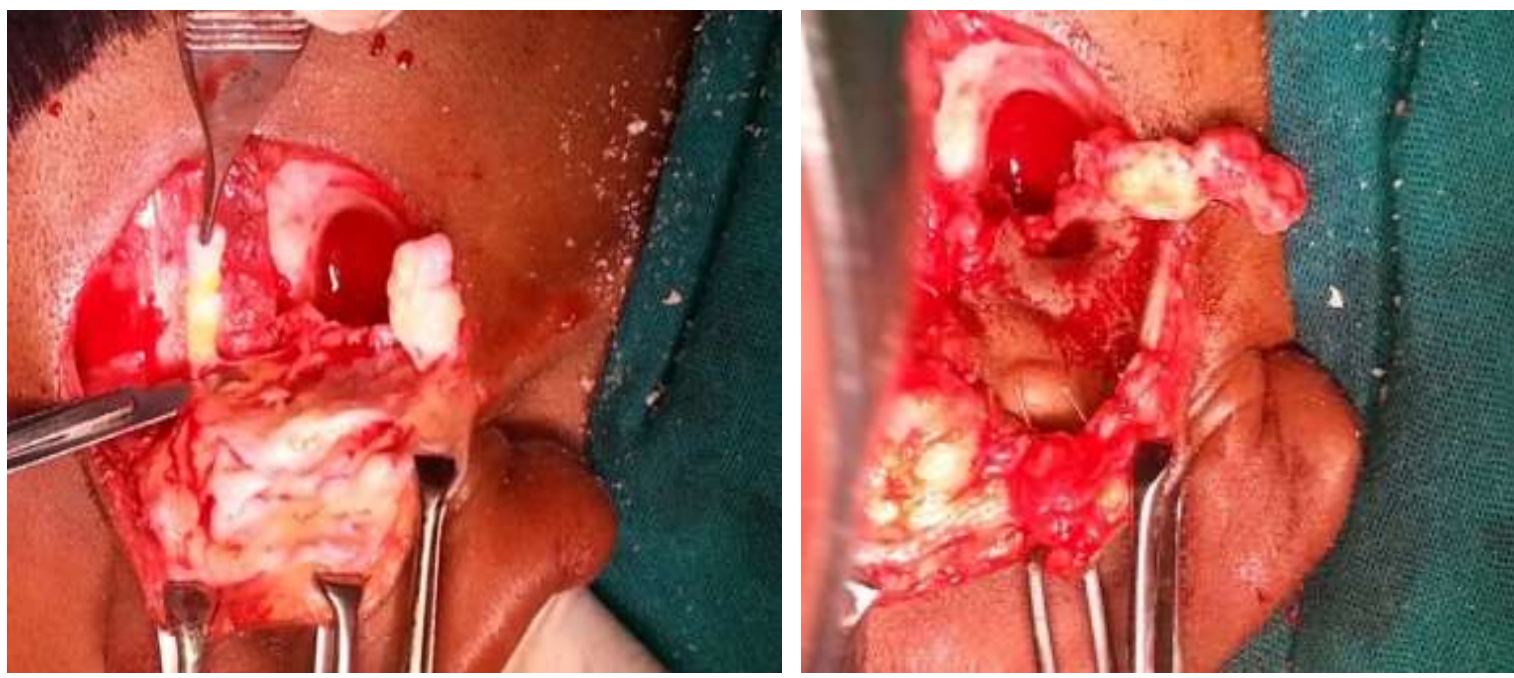

Figure Bits of Fibro Fatty Tissues

Figure 1FILLING THE CAVITY WITH 


\section{BITS OF FIBRO FATTY TISSUE AND}

CARTILAGE
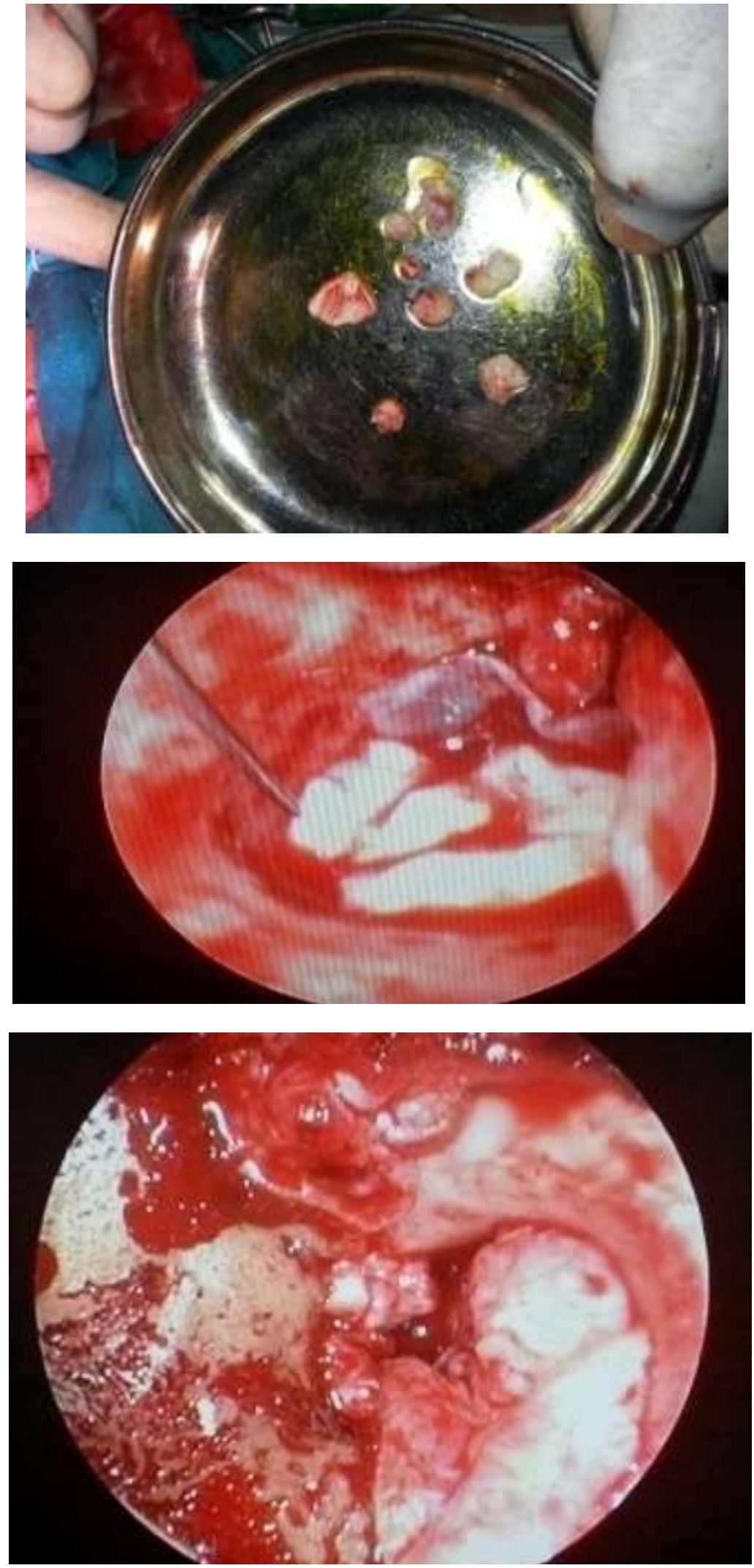
Figure 2 NON AESTHETIC MEATOPLASTY IN NON OBLITERATED CAVITY

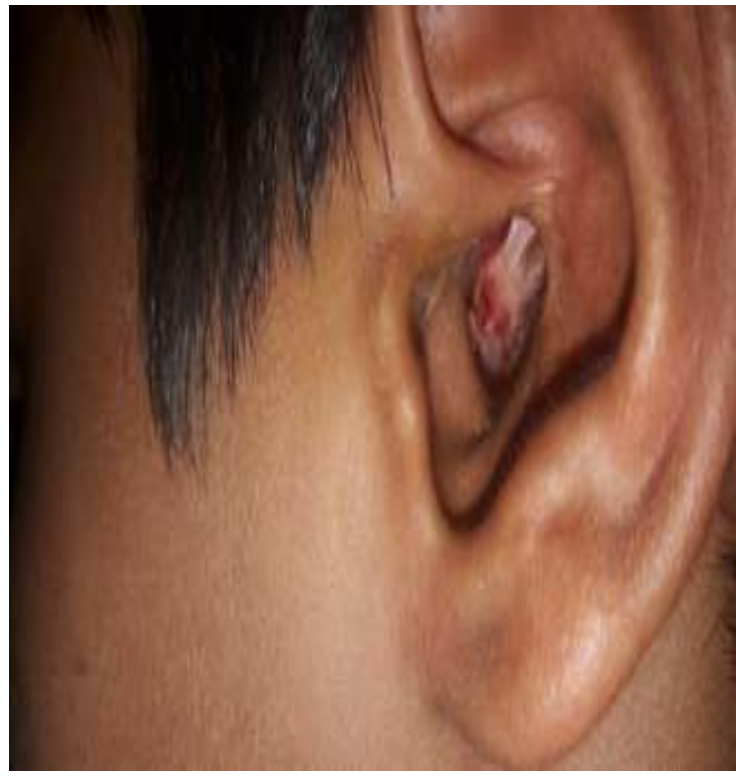

Figure 4DRY WELL EPTHELIZED CAVITY OBLITERATION WITH NEOTM

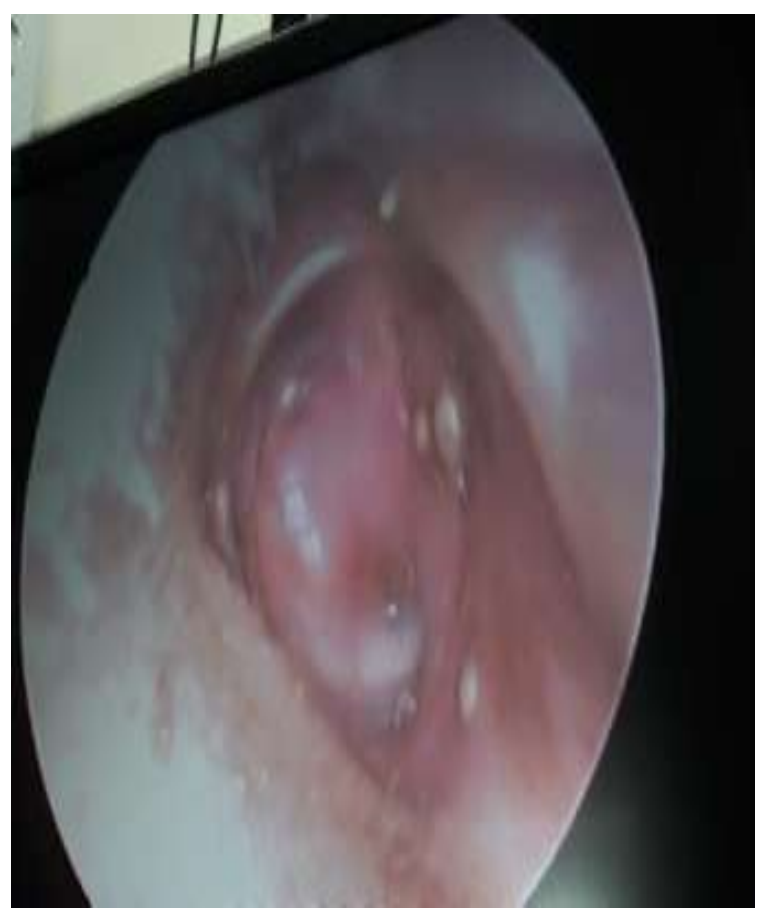

Figure 3 AESTHETIC MEATOPLASTY IN CAVITY OBLITERATION

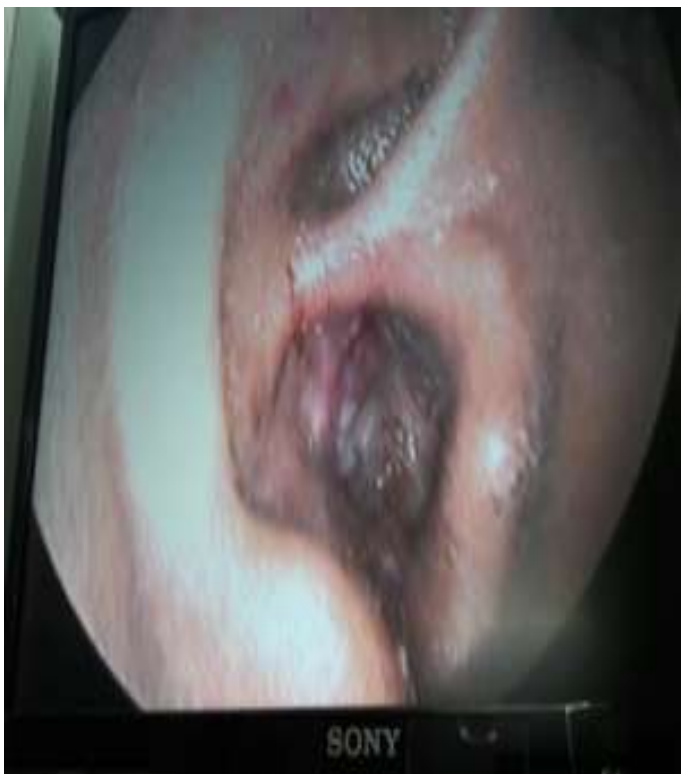

Figure 5HEALING PHASE OF OBLITERATED CAVITY

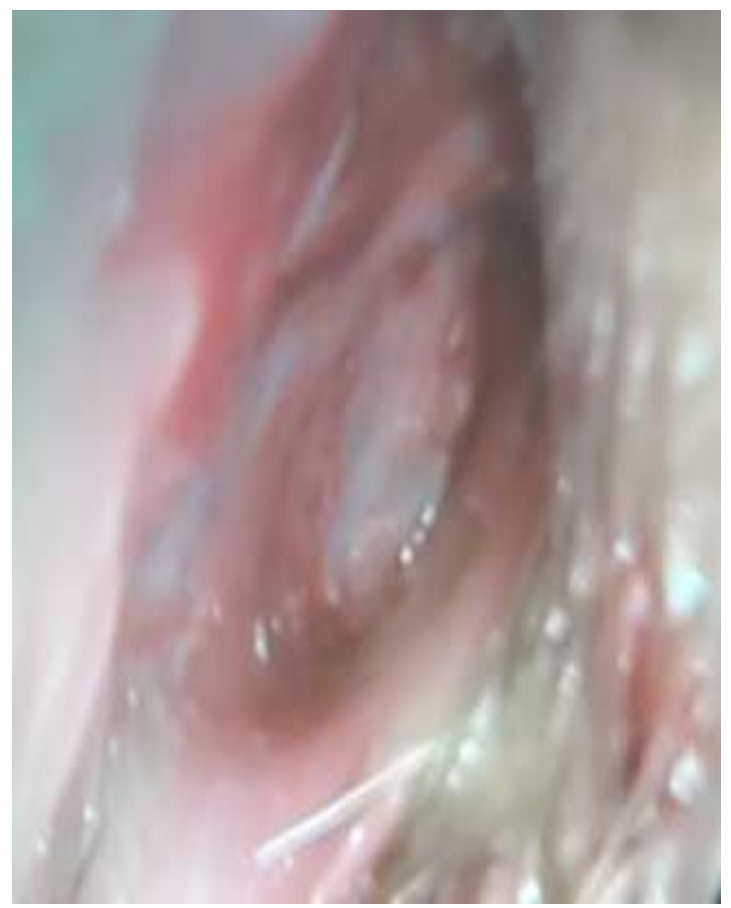

Meatoplasty with partly removing the conchal cartilage 


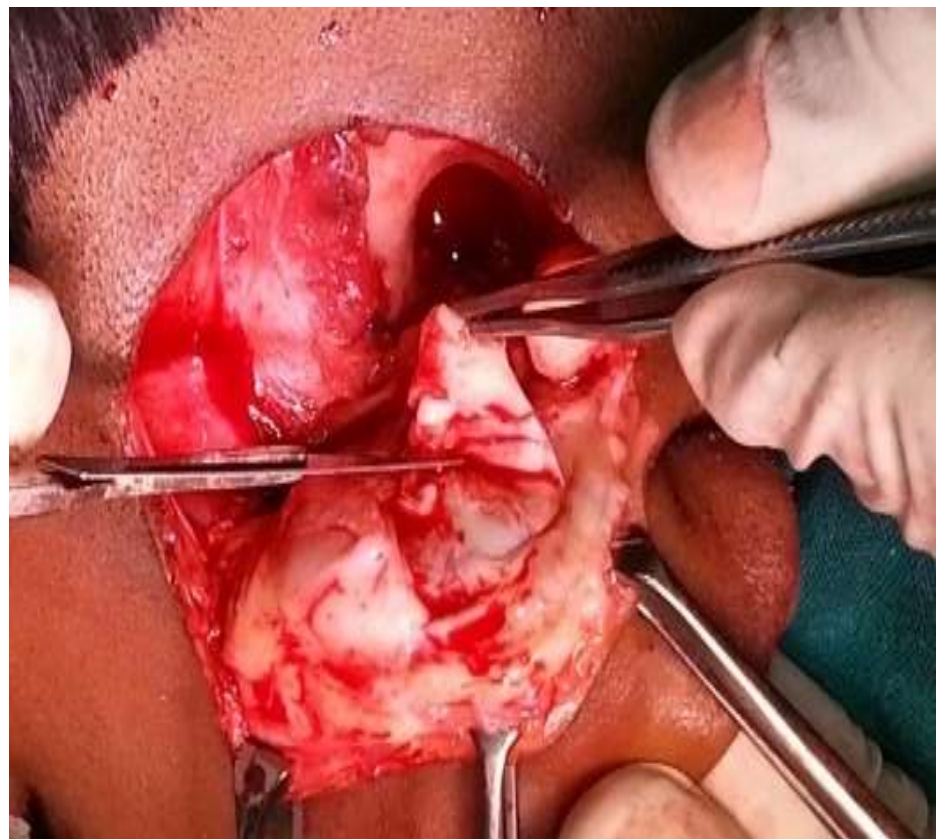

ENT Cases of various diseases in OPD - 2015 June-2016 June

\begin{tabular}{|l|c|}
\hline No of pts visiting ENT op per day & 100 \\
\hline Tonsillitis cases & 10 \\
\hline Nonspecific throat pain & 15 \\
\hline Non specific Neck pains & 5 \\
\hline Nasal obstruction (DNS) & 14 \\
\hline CSOM & 30 \\
\hline Tubotympanic type & 25 \\
\hline Attico antral type & 5 \\
\hline Fb ear & 1 \\
\hline Tear ear lobule & 1 \\
\hline Malignancies & 1 \\
\hline Sinusitis & 1 \\
\hline Horseness of voice & 1 \\
\hline & \\
\hline Headache & 7 \\
\hline Neck swellings & One or non \\
\hline Dysphagia & 4 \\
\hline
\end{tabular}

ENT OPD census in 2015 June-2016 May at RIMS Ongole

\begin{tabular}{|l|c|}
\hline Total no of ENT pts per month & 2600 \\
\hline Per annum & 31,200 \\
\hline CSOM cases per month & 780 \\
\hline Granulations & 300 \\
\hline Polypiod granulations & 100 \\
\hline Per annum & 9360 \\
\hline Out of 9360 tubotympani type & 7800 \\
\hline Attico antral type & 1560 \\
\hline Cholesteatoma & 1000 \\
\hline Retraction pockets & 60 \\
\hline
\end{tabular}

ENT surgeries performed in 2015 June-2016 May at RIMS Ongole

\begin{tabular}{|l|c|}
\hline $\begin{array}{l}\text { No ENT surgeries performed per } \\
\text { month }\end{array}$ & $\mathbf{8 0}$ cases \\
\hline No of ear surgeries & $\mathbf{3 0}$ \\
\hline Myringo plasties & 15 \\
\hline $\begin{array}{l}\text { Mastiodectomies with } \\
\text { tympanoplasties }\end{array}$ & 10 \\
\hline MRM with cavity obliteration & 5 \\
\hline Per annum ear surgeries & $\mathbf{3 6 0}$ \\
\hline Myringoplasties & 180 \\
\hline Mastiodectiomies & 120 \\
\hline MRM & 60 \\
\hline
\end{tabular}


Mastoid cavity obliteration in open cavity type (MRM) with fibro fatty tissue and subcutaneous...

Grafical representation of ENT surgeries performed 1in 2015 June-2016 June

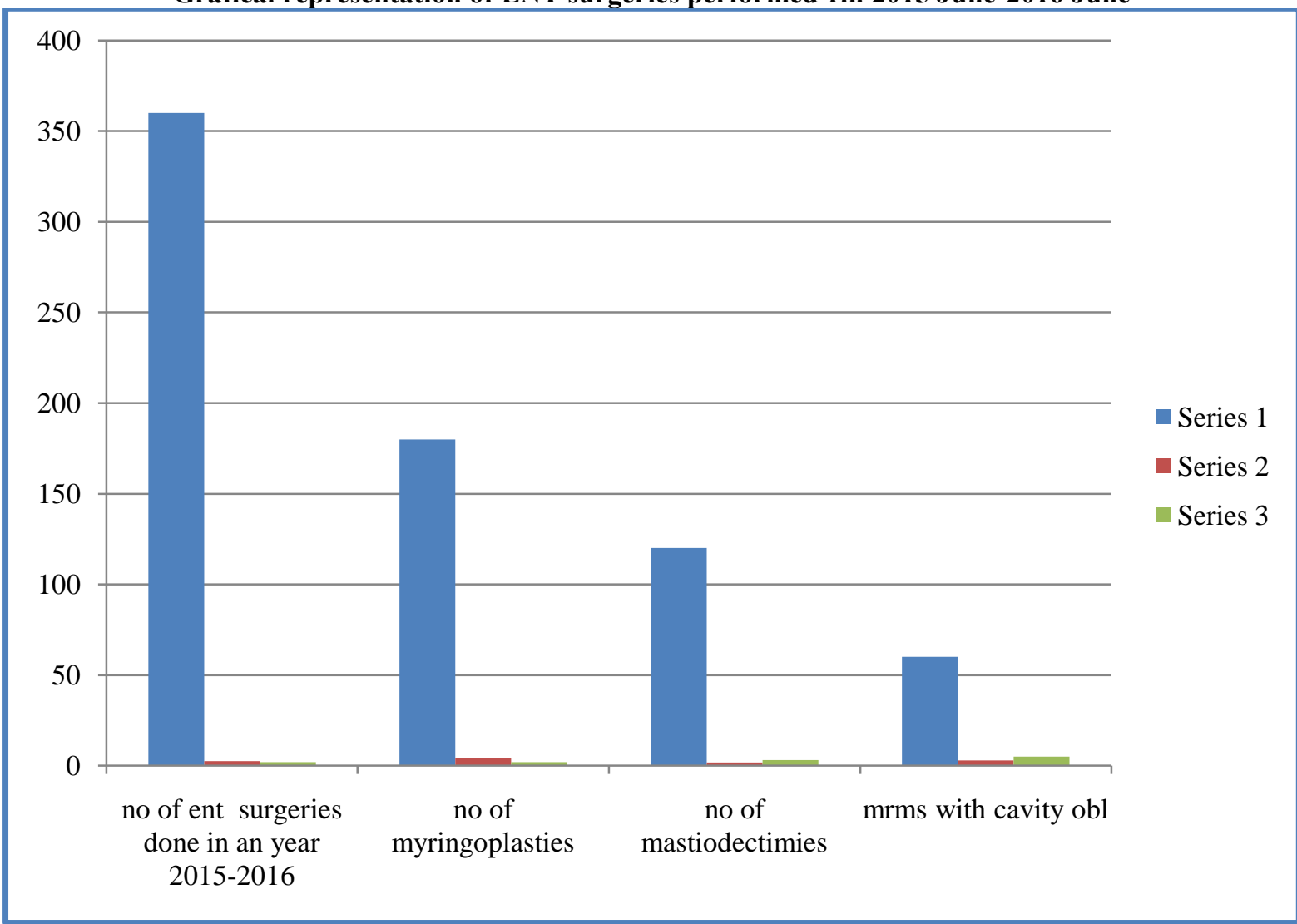

Graphical representation of ENT cases with CSOM

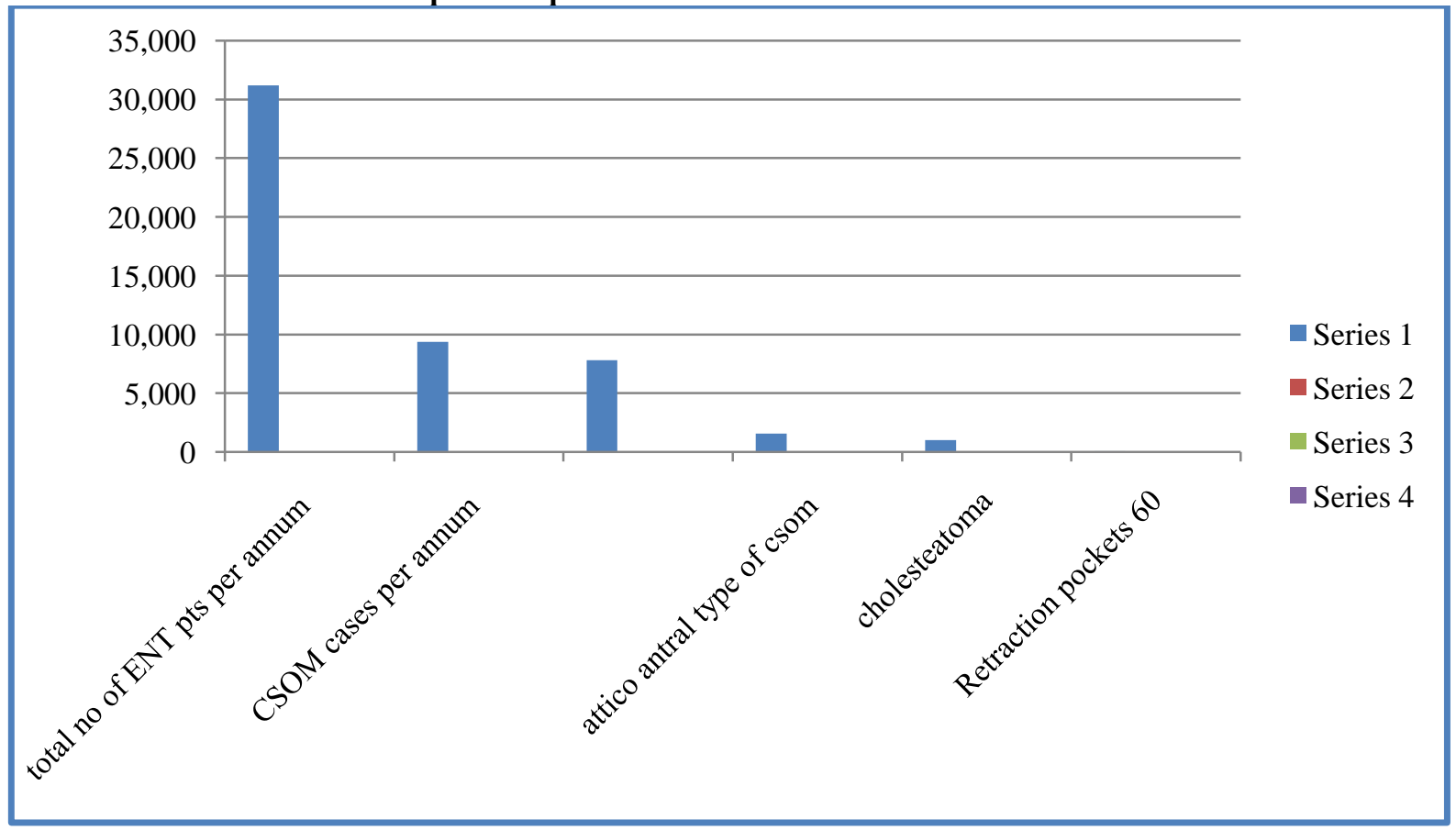




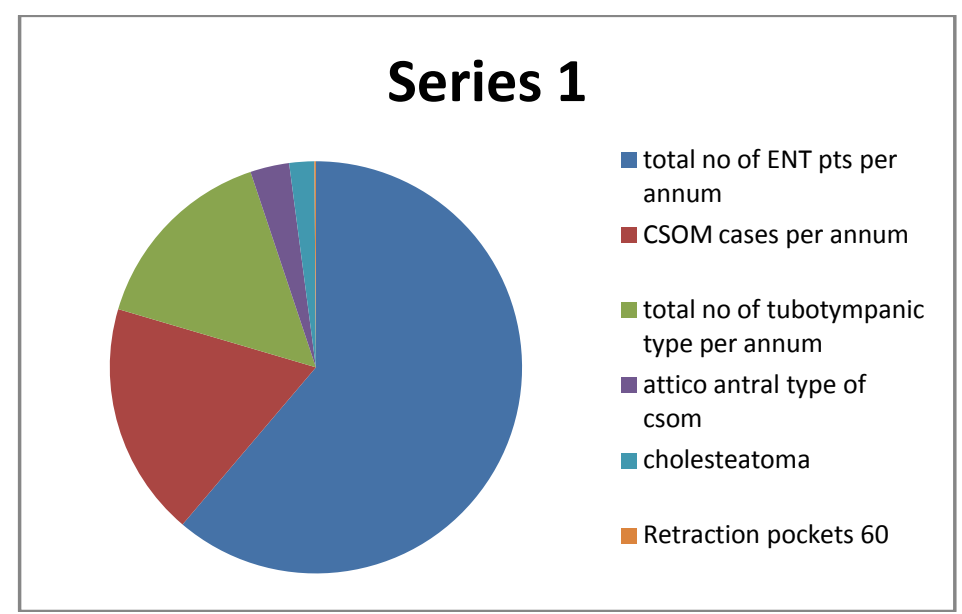

